\title{
A short history of SLA: Where have we come from and where are we going?
}

\author{
Rod Ellis \\ Curtin University, Perth, Australia \\ E-mail: r.ellis@auckland.ac.nz
}

\section{Introduction}

If we want to understand where we are now, we need to consider where we have come from. This statement constitutes the strongest rationale for the study of history. It is relevant to any field of enquiry and it is certainly true of the field of second language acquisition (SLA). ${ }^{1}$ As Larsen-Freeman (2018) wrote in her own historical account of SLA it is important to understand ideas at the time they originated' (p. 56). I would add that it is also important to understand how the ideas that motivated a field of enquiry at one time evolved into and were sometimes replaced by ideas later on.

Let me begin with some personal history.

My own interest in SLA began while I was a teacher in Africa in the late 1960s. I worked in a newly built, rural (bush) secondary school in Zambia with no training in how to teach English to second language (L2) learners but with three months' experience of teaching in a Berlitz school in Spain. My initial concern was solely with what and how I should teach English. However, it soon became clear to me that students frequently failed to learn what I taught them and that there was an obvious gap between 'teaching' and 'learning'. On leaving Zambia I enrolled in an M.A. in Linguistics and Language Teaching at the University of Leeds in order to deepen my professional understanding of language teaching and learning and, of course, to further my career prospects. I was introduced to Chomsky's transformational generative grammar, which had only recently appeared on the scene, and to the idea that we all possess an innate faculty for language that determines how we learn our mother tongue. There was, however, very little in the M.A. programme about L2 learning and not much about teaching. I do remember, however, a lecture based on Newmark's (1966) article: 'How not to interfere in language learning'. This floated the interesting idea that it was neither necessary nor helpful for teachers to present and practise specific linguistic items as learners acquire an L2 in the same way as children acquire their first language (L1) - by drawing on the innate faculty for language.

So like many other SLA researchers, my initial interest in L2 acquisition was rooted in my practical concern to make language teaching effective and this is where I still am now. But looking back I can see that my journey with SLA has involved phases. The initial phase was clearly an applied one. I studied how L2 learners learn with a view to extracting sound principles and practices for language teaching. Subsequently, however, my interest was more one of intellectual curiosity and I oriented to SLA for its own sake. I completed empirical studies of L2 acquisition and I wrote increasingly lengthy survey books. During this phase, I was still concerned with language teaching but SLA was no longer just an 'applied' discipline of practical significance for me but also a 'pure' one of intrinsic interest. In this respect, I think I am representative of how SLA has evolved in general. In my more recent years, however, my interest in pure SLA has waned and I now once again have a more applied perspective.

This paper is based on the presentation given by Professor Ellis at the Annual Conference of the Australian and New Zealand Associations of Applied Linguistics (ALAA/ALANZ), Perth, Australia, 25-27 November 2019.

(c) The Author(s), 2020. Published by Cambridge University Press 
Table 1. Making a start

\begin{tabular}{|c|c|c|c|c|}
\hline Area of interest & Period & Key studies & Key findings & Theoretical influences \\
\hline $\begin{array}{l}\text { Order and } \\
\text { sequence of } \\
\text { acquisition }\end{array}$ & $\begin{array}{l}\text { 1960s } \\
\text { and } \\
1970 \mathrm{~s}\end{array}$ & $\begin{array}{l}\text { Dulay and Burt (1973) } \\
\text { and Cancino, } \\
\text { Rosansky, and } \\
\text { Schumann (1978) }\end{array}$ & $\begin{array}{l}\text { Just as children acquiring their first } \\
\text { language went through clearly } \\
\text { marked stages of development, so } \\
\text { too do child and adult L2 learners } \\
\text { acquire the grammar of an L2 in a } \\
\text { more-or-less universal and fixed } \\
\text { way. This finding challenged } \\
\text { behaviourist accounts of L2 } \\
\text { learning and the audiolingual } \\
\text { method of teaching. }\end{array}$ & $\begin{array}{l}\text { L1 acquisition research } \\
\text { (e.g. Klima \& } \\
\text { Bellugi, 1966; } \\
\text { Brown, 1973). }\end{array}$ \\
\hline
\end{tabular}

However, whereas initially I took as my starting point information about how learners learn and then looked to how to apply this to language teaching, I now took language pedagogy as that starting point and looked to see how SLA could support and sometimes challenge widely held assumptions about language pedagogy. Thus, I can somewhat crudely plot my involvement with SLA as a progression from an initial theory-to-practice approach to a theory-and-research perspective and finally to a practice-then-theory approach.

My personal history reflects what has happened to SLA over the years. SLA began as an applied discipline. Increasingly, however, separate perspectives have emerged - 'applied SLA' continues to address issues of social and, in particular, pedagogical importance while 'pure SLA' aims to contribute to our understanding of the nature of the human language faculty. This bifurcation is evident in the journals that publish SLA research today - for example, Language Teaching Research and Instructed Language Acquisition cater to applied SLA while Studies in Second Language Acquisition and Language Learning now increasingly cater to a pure SLA with its close connections to linguistics, psychology and sociology.

I will now present my brief history of SLA. I will address three questions: (1) what aspects of L2 acquisition has SLA has focused on? (2) how have researchers investigated L2 acquisition? and (3) why have researchers investigated L2 acquisition? There have been developments in all of these areas. I will then address where I think SLA is now at and where it should go by asking whether it constitutes an identifiable academic discipline and, if so, what kind of discipline it is.

\section{What aspects of L2 acquisition has SLA addressed?}

Previous histories of SLA identify phases and I will follow suit, dividing 50+ years of enquiry into five phases. Table 1 presents the first phase, which I have called 'Making a start'. ${ }^{2}$ It roughly covered the 1960s and 1970s. The main feature of this phase were the studies of naturalistic L2 learners. Many of these studies were cross-sectional but there were also a number of influential longitudinal studies (e.g. Wode, 1976; Schumann, 1978). A new journal (Working Papers in Bilingualism) published the results of the research. One of the main findings was that learners followed a more-or-less universal and invariable route in acquiring both grammatical morphemes such as plural-s and 3rd person-s and syntactical constructions such as negatives and interrogatives. L2 acquisition seemed to involve a natural process of creative construction, and transfer from the L1 was minimal. Some researchers (e.g. Dulay \& Burt, 1975; Krashen, 1977) drew on these findings to argue that there was no need to teach grammar, thus challenging prevailing views about language teaching. However, not all SLA researchers were so ready to advance pedagogic applications. Hatch (1978b), for example, argued the need for caution and suggested that what had been learned about L2 acquisition was not, in fact, so incompatible with the standard pedagogic practices of the day.

I have labelled the second phase the 'expansion period'. During this period SLA broadened the scope of its enquiry considerably. As Table 2 shows, four major areas of enquiry developed - 
Table 2. The expansion period

\begin{tabular}{|c|c|c|c|c|}
\hline Area of interest & Period & Key studies & Key findings & Theoretical influences \\
\hline $\begin{array}{l}\text { Language } \\
\text { transfer }\end{array}$ & $1980 \mathrm{~s}$ & $\begin{array}{l}\text { Kellerman (1983) and } \\
\text { Ringbom (1987) }\end{array}$ & $\begin{array}{l}\text { Language transfer was reconceptualized as a cognitive } \\
\text { rather than behaviourist phenomenon; the emphasis was } \\
\text { now on the conditions that governed negative and } \\
\text { positive transfer and avoidance. }\end{array}$ & $\begin{array}{l}\text { Reaction to both behaviourist accounts (e.g. } \\
\text { Lado, 1957) and the minimalist position } \\
\text { (Krashen, 1983). }\end{array}$ \\
\hline $\begin{array}{l}\text { Linguistic } \\
\text { universals } \\
\text { Universal } \\
\text { Grammar } \\
\text { (UG) }\end{array}$ & $1980 \mathrm{~s}$ & $\begin{array}{l}\text { Gass (1984), White (1989) } \\
\text { and Eckman, Bell, and } \\
\text { Nelson (1988) }\end{array}$ & $\begin{array}{l}\text { Researchers tested hypotheses drawn from linguistics - in } \\
\text { particular whether L2 learners had access to UG. } \\
\text { Markedness and universal principles governed both } \\
\text { order of acquisition and language transfer. }\end{array}$ & $\begin{array}{l}\text { Linguistic theory: Typological universals - } \\
\text { (Comrie, 1984); Generative grammar - } \\
\text { (Chomsky, 1965). }\end{array}$ \\
\hline $\begin{array}{l}\text { Second } \\
\text { language } \\
\text { pragmatics }\end{array}$ & $1980 \mathrm{~s}$ & $\begin{array}{l}\text { Thomas (1983) and } \\
\text { Blum-Kulka, House, } \\
\text { and Kasper (1989) }\end{array}$ & $\begin{array}{l}\text { The focus was on the comprehension and production of } \\
\text { speech acts such as requests and apologies and the } \\
\text { identification of pragmatic and pragmalinguistic } \\
\text { differences between native and non- native speakers. }\end{array}$ & $\begin{array}{l}\text { Speech act theory (Searle, 1969); politeness } \\
\text { theory (Brown \& Levinson, 1987). }\end{array}$ \\
\hline $\begin{array}{l}\text { Input and } \\
\text { interaction }\end{array}$ & $1980 \mathrm{~s}$ & $\begin{array}{l}\text { Krashen (1985), Long } \\
(1983) \text { and Swain } \\
(1985)\end{array}$ & $\begin{array}{l}\text { Researchers addressed how the linguistic environment } \\
\text { influenced L2 acquisition. Three influential hypotheses: } \\
\text { (1) the Input Hypothesis, (2) the Interaction Hypothesis } \\
\text { and (3) the Comprehensible Output Hypothesis. }\end{array}$ & $\begin{array}{l}\text { Research on foreigner talk - (Ferguson, } \\
\text { 1975); L1 acquisition research on caretaker } \\
\text { talk - (Wells, 1985); discourse analysis - } \\
\text { (Coulthard, 1977). }\end{array}$ \\
\hline
\end{tabular}


language transfer, linguistic universals, second language pragmatics, and input/interaction. In this period SLA reached out to a range of established disciplines - linguistics, sociolinguistics and discourse analysis - drawing on these to investigate different aspects of learner-language and learning. If the first period was very much a research-then-theory approach, loosely informed by work in L1 acquisition, this phase was more theory-then-research. Interest in the pedagogical applications of research continued but researchers did not always include an implications/applications section in their published papers. SLA was emerging as a 'pure' discipline. Research on input and interaction, however, had obvious relevance to language pedagogy and it was during this period that the first proposal for task-based language teaching - an approach that draws directly on the findings of SLA research - appeared (Long, 1985). All the areas of interest in Table 2 have continued to figure strongly in SLA today.

The next phase (Table 3) represents a 'coming of age' (Sharwood-Smith, 1994). It is really an extension of the previous one but I prefer to view it as distinct because it reflected the impact that constructs taken from cognitive psychology had on thinking about L2 acquisition. Information-processing theories are premised on an input-output view of learning and what Lantolf (1996) called the 'computational model'. Key constructs investigated were 'attention' and 'skill learning'. During this period, too, interest in implicit and explicit learning led to a refinement of Krashen's (1981) earlier 'acquisition' and 'learning' distinction. Researchers borrowed from different strands of research in cognitive psychology, leading to alternative views about the role of consciousness in language learning, with some researchers (e.g. Schmidt, 1990) arguing that some level of consciousness was always needed and others (e.g. Tomlin \& Villa, 1994) that learning could be entirely implicit. Another area of controversy concerned whether language learning (especially by adults) involved skill-learning (i.e. where the starting point was declarative knowledge) or was an essentially implicit process. These controversies were of clear significance for language pedagogy and a key issue became the nature of the interface between explicit/declarative and implicit/procedural knowledge. The non-interface (Krashen, 1981), strong-interface (DeKeyser, 1998), and weak interface (R. Ellis, 1994) positions led to very different proposals regarding the role and nature of explicit grammar instruction.

It would be wrong to claim that SLA had paid no attention to social factors up to this point. Schumann's (1978) Acculturation Model, for example, was an attempt to explain how social as well as psychological distance from the target-language community affected learners' access to and acquisition of the target language. This model, however, did not receive strong empirical support and reflected a very deterministic view of the relationship between social context and learning. Towards the end of the 1990s, SLA researchers (e.g. Firth \& Wagner, 1997) turned to poststructuralist accounts that emphasized learners' own agency in constructing social opportunities for learning and the importance that social identity played in this. This began what became called the 'social turn' in SLA (Block, 2003) and the claims that L2 acquisition cannot be explained in purely cognitive terms, that learners are complex social beings, and that L2 acquisition is best understood by studying how individual learners both respond to and shape their social context. Poststructuralist theories (e.g. Bourdieu, 1986) and social theories such as Community of Practice Theory (Lave \& Wenger, 1991) provided the constructs and tools for re-thinking SLA as a primarily social phenomenon. However, this broadening of the field was not welcomed by all researchers, with Long in particular arguing that SLA should remain a cognitive enterprise (Long, 1998; Long \& Doughty, 2003).

I have included sociocultural SLA in this period although it constitutes a very different kind of social turn (Table 4) and pre-dated Firth and Wagner (1997). As applied to SLA, sociocultural theory emphasizes the role that mediation plays in the initial development and subsequent internalization of new knowledge. Unlike other social theories, it recognizes the 'mind' as a central component in learning. Like cognitive-interactionist theories, it emphasizes the importance of interaction in L2 acquisition but it differs from these theories in how it conceptualizes the role of interaction. Whereas cognitive-interactionist theories see interaction as a source of input and output that is processed through internal cognitive mechanisms, sociocultural SLA views development as originating in the interactions that learners participate in with others or, in the case of private speech, with themselves. 
Table 3. Cognitive phase

\begin{tabular}{|c|c|c|c|c|}
\hline Areas of interest & Period & Key studies & Key findings & $\begin{array}{l}\text { Theoretical } \\
\text { influences }\end{array}$ \\
\hline $\begin{array}{l}\text { Consciousness and } \\
\text { L2 acquisition; } \\
\text { implicit and } \\
\text { explicit } \\
\text { knowledge; } \\
\text { emergentism; } \\
\text { skill learning } \\
\text { theory }\end{array}$ & $\begin{array}{l}\text { Late } 1990 \text { s } \\
\text { onwards }\end{array}$ & $\begin{array}{l}\text { Schmidt (1990), } \\
\text { Tomlin and } \\
\text { Villa (1994), } \\
\text { Ellis (1994) } \\
\text { and DeKeyser } \\
\text { (1998) }\end{array}$ & $\begin{array}{l}\text { Conscious attention to } \\
\text { exemplars of } \\
\text { linguistic features in } \\
\text { input and output } \\
\text { ('noticing') required } \\
\text { for acquisition; } \\
\text { implicit and explicit } \\
\text { knowledge are } \\
\text { fundamentally } \\
\text { different with } \\
\text { implicit knowledge } \\
\text { primary; interface } \\
\text { positions. }\end{array}$ & $\begin{array}{l}\text { Cognitive } \\
\text { psychology - } \\
\text { information } \\
\text { processing } \\
\text { models; } \\
\text { implicit/explicit } \\
\text { knowledge } \\
\text { (Reber, 1976, } \\
\text { 1993); Adaptive } \\
\text { Control of } \\
\text { Thought - } \\
\text { Rational Theory } \\
\text { (ACT-R) } \\
\text { (Anderson, } \\
\text { 1980). }\end{array}$ \\
\hline
\end{tabular}

Table 4. The social turn

\begin{tabular}{|c|c|c|c|c|}
\hline $\begin{array}{l}\text { Area of } \\
\text { interest }\end{array}$ & Period & Key studies & Key findings & Theoretical influences \\
\hline $\begin{array}{l}\text { The Social } \\
\text { Turn }\end{array}$ & $\begin{array}{l}\text { Late } 1990 \text { s } \\
\text { onwards }\end{array}$ & $\begin{array}{l}\text { Firth and } \\
\text { Wagner } \\
\text { (1997), } \\
\text { Block } \\
\text { (2003) and } \\
\text { Norton } \\
(2000)\end{array}$ & $\begin{array}{l}\text { Learners have agency and } \\
\text { actively construct their own } \\
\text { learning contexts; social } \\
\text { identity is crucial; learner- } \\
\text { learner interactions are } \\
\text { common; learners have local } \\
\text { agendas. }\end{array}$ & $\begin{array}{l}\text { Socialization theories e.g. } \\
\text { Community of Practice } \\
\text { Theory (Lave \& Wenger, } \\
\text { 1991); Poststructuralist } \\
\text { theories (Bourdieu, 1986). }\end{array}$ \\
\hline $\begin{array}{l}\text { Sociocultural } \\
\text { SLA }\end{array}$ & $\begin{array}{l}\text { 1990s } \\
\text { onwards }\end{array}$ & $\begin{array}{l}\text { Lantolf (2000) } \\
\text { and Swain } \\
(2006)\end{array}$ & $\begin{array}{l}\text { Learning commences externally } \\
\text { WITHIN interaction. } \\
\text { Key constructs - mediation; } \\
\text { private speech; zone of } \\
\text { proximal development; } \\
\text { internalisation; collaborative } \\
\text { dialogue; 'languaging'; } \\
\text { dynamic assessment. }\end{array}$ & $\begin{array}{l}\text { Sociocultural theory - } \\
\text { (Vygotsky, 1978, 1986). } \\
\text { Sociocognitive theory } \\
\text { (Atkinson, 2014). }\end{array}$ \\
\hline
\end{tabular}

Sociocultural theory is a theory that incorporates both the 'participation' and the 'acquisition' metaphors (Sfard, 1998). It has led to some rich pedagogic applications, notably the importance of 'languaging' (Swain, 2006) for learning.

We have reached the 2000s. Much of the developments that took place in the 1980s and 1990s carried on into the 2000s but two new developments are noteworthy (Table 5). The first is Complex Dynamic Systems Theory. This represents a coming together of Complexity Theory (Larsen-Freeman \& Cameron, 2008) and Dynamic Systems Theory (de Bot, Lowie, \& Verspoor, 2007), which share a set of fundamental precepts, for example, that language systems are non-linear, highly variable, individualistic, nonpredictable and always open to change. This theory emphasizes the need to take account of the interconnectedness of social, cognitive and psychological factors and thus offers an all-embracing framework for investigating both the use and acquisition of an L2 and individual learner differences. Larsen-Freeman (2018) sees it as theory fit for the globalized world of today, which 'requires a more holistic, ecological, and relational systems account as a complement' (p. 59). It is, however, a theory that is not easy to investigate empirically given the need to include in the design of a study the countless variables that can influence L2 acquisition. The research that has appeared to date does not satisfy this 
Table 5. Recent developments

\begin{tabular}{|c|c|c|c|c|}
\hline Area of interest & Period & Key studies & Key findings & Theoretical influences \\
\hline $\begin{array}{l}\text { Complex } \\
\text { Dynamic } \\
\text { Systems } \\
\text { Theory }\end{array}$ & $\begin{array}{l}2000 s \\
\text { onwards }\end{array}$ & $\begin{array}{l}\text { Larsen-Freeman } \\
\text { (1997), } \\
\text { Larsen-Freeman } \\
\text { and Cameron } \\
\text { (2008) and de Bot } \\
\text { et al. (2007) }\end{array}$ & $\begin{array}{l}\text { Combines social and } \\
\text { cognitive perspectives on } \\
\text { L2 acquisition; views } \\
\text { learning as individualistic } \\
\text { and non-linear; } \\
\text { interconnectedness of } \\
\text { multiple variables; } \\
\text { predictions about how } \\
\text { learning will occur not } \\
\text { possible. }\end{array}$ & $\begin{array}{l}\text { Originated in } \\
\text { mathematics and } \\
\text { science - e.g. } \\
\text { Catastrophe Theory } \\
\text { and Chaos Theory; } \\
\text { also influenced by } \\
\text { emergentist theories } \\
\text { of learning. }\end{array}$ \\
\hline $\begin{array}{l}\text { The multilingual } \\
\text { turn }\end{array}$ & $2010 \mathrm{~s}$ & $\begin{array}{l}\text { Cook (1992), May } \\
(2013) \text { and Ortega } \\
(2009,2019)\end{array}$ & $\begin{array}{l}\text { Rejects viewing bilingualism } \\
\text { in terms of the } \\
\text { development of } \\
\text { monolingual competence; } \\
\text { makes multilingualism the } \\
\text { central area of enquiry and } \\
\text { emphasizes the multiple } \\
\text { competencies of bi/ } \\
\text { multilingual learners; } \\
\text { translanguaging. }\end{array}$ & Transdisciplinary \\
\hline
\end{tabular}

requirement nor, to my mind, is it possible to do so. I see Complex Dynamic Systems Theory not as a testable theory but as a useful metaphor of the wholeness of L2 acquisition. ${ }^{3}$

The second development is the 'multilingual turn' - a more inclusive construct than 'social turn'. Firth and Wagner (1997) criticized cognitive SLA's assumption that L2 learners target the competence of a monolingual native speaker. Later, Ortega (2009) pointed out that 'when we oppose L2 acquisition to L1 acquisition a subtle but dangerous monolingual bias seeps into our imagination' (p. 5). This perspective led to proposals for redirecting SLA to the investigation of multicompetences (Cook, 1992) and the translanguaging that occurs amongst mixed groups of language users who draw on multiple linguistic resources (May, 2013). The multilingual turn shares with Complex Dynamic Systems Theory a view of the L2 learner as complex and heterogeneous - a view that is far removed from that of the reified non-native speaker of much earlier SLA research.

From this brief history of the development of SLA, we can extract a few generalizations:

1. Many of the issues that figured in the early days of SLA have continued to figure in subsequent periods. However, researchers revisited these issues in new ways, drawing on an increasing range of theoretical perspectives.

2. SLA has become increasingly transdisciplinary and fragmented.

3. Correspondingly, theories have multiplied. While some theories have lost followers over the years (e.g. Krashen's Monitor Model), many have survived (e.g. Long's Interaction Hypothesis). Differences exist as to whether to let all the flowers bloom (Lantolf, 1996) or to cull those theories that can be shown to be demonstrably poor theories (Long, 1993). Little culling has in fact taken place although some theories - such as Schumann's Acculturation Model (Schumann, 1978) - do gradually fall out of fashion.

4. Tensions exist among SLA researchers not just with regard to the details of specific theories but to the overall orientation of SLA. In particular, we find some SLA researchers clinging to a purely cognitive view of L2 acquisition (see, for example, Long \& Doughty, 2003), others to a social view (e.g. Firth \& Wagner, 1997, 2007), and still others adopting a broader socio-cognitive position (e.g. Atkinson, 2014).

5. Not all SLA researchers have been interested in pedagogical applications; not all theories (Universal Grammar being one) have much to say to teachers. 


\section{How have researchers investigated L2 acquisition?}

Concurrent with the growth of SLA, as it drew on an ever-increasing number of other disciplines, is the expanding range of research tools used to investigate L2 acquisition - see Mackey and Gass (2016) for an up-to-date account of second language research methods. Here I will comment on some of the key changes in research approaches that have occurred as SLA has evolved.

Etic and emic perspectives have figured throughout SLA but the popularity of one or the other has varied over time. An etic perspective requires researchers to act as an observer of learners' behaviour. Central to SLA throughout its history is the study of learner-language and the methods used to analyse this have been primarily etic. An emic perspective necessitates investigating learners' subjective understandings of their own behaviour. It helps to identify the factors that influence individual learners' use and acquisition of an L2. Both perspectives were evident from the beginning of SLA. Hatch's (1978a) collection of studies of L2 learners is a good example of the etic approach but at the same time there were also reports of individual learners based on the journals they kept (e.g. Schumann \& Schumann, 1977). The coming-of-age and cognitive periods that spanned the 1980s and 1990s were predominantly etic in orientation but it is not hard to also find influential emic-type studies (e.g. Schmidt \& Frota, 1986; Norton Peirce, 1995). The social turn prioritized emic-type research - for example, the use of narrative inquiry to investigate learning in different social contexts (Barkhuizen, 2014). However, conversational analysis - also a popular tool in socially oriented research - is fundamentally etic in approach. Complex Dynamic Systems Theory requires researchers to address the range of linguistic, social and psychological variables involved in L2 performance and thus demands both approaches. The multilingual turn most clearly prioritizes emic-type research; for example, whereas research on code shifting was inherently etic, accounts of translanguaging involve emic-type methodologies. Increasingly, researchers have turned to mixed-method approaches, combining etic and emic lines of enquiry. For example, cognitive-interactionist studies continue to rely on observation but also make use of strategies to investigate learners' subjective responses to the L2 activities they engage in (e.g. Révész, Michel, \& Gilabert, 2016).

Cutting across the etic-emic distinction is whether the research focuses on groups of learners or on individuals. In general, etic research investigates groups of learners while emic research aims for rich data about individual learners. The morpheme studies of the 1970s involved groups and, with a few exceptions, were cross-sectional but the studies investigating transitional constructions at this time investigated individual learners and were longitudinal. In the expansion and cognitive phases of SLA, researchers investigated groups of learners in cross-sectional studies. Social turn researchers prioritized individuals but rarely longitudinally (see, for example, Norton, 2000). Larsen-Freeman (2018) emphasized the importance of investigating individual learners. She disputed the assumption that group averages can say anything about the population under investigation. She also expressed wariness about pooling findings from studies of individual learners in the search for post-hoc generalizations. For her, SLA research is all about particularization, not generalization, a point I will also return to later. In the introduction to their Handbook of second language acquisition, Doughty and Long (2003) lamented the lack of longitudinal studies. The situation has changed little since then but see Ortega and Byrnes (2008) collection of longitudinal studies of advanced L2 learners.

Samples of learner language constitute the primary data for investigating acquisition so a key issue is how to collect and analyse these samples. Ellis and Barkhuizen (2005) distinguished three basic types of samples - naturally occurring language use (i.e. language produced in a real-life situation), clinically elicited data (i.e. general samples of language elicited by means of tasks), and experimentally elicited data (i.e. samples of the use of specific, pre-determined linguistic features elicited by means of tests). In SLA, there is a general preference for samples of naturally occurring language use but these are often difficult to obtain and may not contain instances of the particular features under investigation. As a result, researchers have frequently resorted to collecting clinically elicited samples (e.g. using tasks) or experimentally elicited samples (e.g. by means of grammatically judgement tests). The key issue is the theoretical validity of the elicited samples, in particular the experimentally elicited ones. 
The issue here is what the samples tell us about acquisition. While researchers have always recognized this issue, they have largely ignored it, often happy to talk about acquisition with no consideration of the type of data they had collected. The interest in implicit and explicit knowledge that arose in the 1990s during the cognitive period of SLA led to attempts to investigate the knowledge underlying different types of data. In Ellis (2005), I reported a study that used factor-analysis to show that some types of elicited data (e.g. an oral elicited imitation test) resulted in a different type of language use from other types (e.g. an untimed grammaticality judgement test) and suggested that this difference reflected the difference between implicit and explicit L2 knowledge. This article has generated a whole series of studies, some supporting and others challenging the findings of the 2005 study on the grounds that the oral elicited imitation test is not a true test of implicit knowledge. This body of research testifies to a general development in SLA - the increasing concern with the validity of the methods employed.

Over the years, SLA has grown increasingly more varied and sophisticated in its research methodology. In part, this was in response to the broadening of the field of SLA but it is also a reflection of researchers' increased technical expertise and their willingness to subject the procedures used to collect and analyse data to critical scrutiny. The development of technical expertise is evident in meta-analyses of L2 studies (e.g. Norris \& Ortega, 2000) and in the increasing concern for the proper use of statistics (e.g. Plonsky, 2015). As Loewen and Gass (2009) pointed out, SLA may not be an innovator but it is 'an increasingly knowledgeable borrower and adapter of statistical procedures' (p. 181). Similar developments are evident in the qualitative methodologies employed in SLA (e.g. Davis, 2012). SLA in 2019 is a much more rigorous enterprise than in the 1970s.

\section{Why investigate L2 acquisition?}

Survey books of SLA begin by telling their readers the reasons for investigating SLA. In Ellis (1985; 2015), I identified the primary purpose of the book as helping teachers construct 'a theory of language learning that is explicit and therefore open to revision' (p. 3). This reflects the underlying rationale for much of the early SLA research - helping to make language teaching more effective. Larsen-Freeman and Long writing in 1991 also saw SLA as a source of insight about how to teach an L2 by increasing teachers' awareness about the learning process but they also saw it having other purposes - helping populations with specific language learning needs and informing other disciplines (e.g. by helping to investigate linguists' claims about linguistic universals). The first reason they gave, however, was 'intellectual curiosity' reflecting the fact that by 1991 SLA had already become a self-contained field of study. Mitchell and Myles (1998), in the first edition of their book, saw SLA as informing social practice (most obviously language teaching) but gave as their primary reason the contribution that SLA can make to 'fundamental understandings' such as the workings of the human mind. They also noted that there were diverging opinions about SLA's links to social practice, with some researchers arguing for pure-theory building, others for engagement with social practice, and still others for guiding language teaching. Doughty and Long (2003) acknowledged the social importance of learning a second language but did not view this as the main reason for studying it. Reflecting their claim that SLA is essentially a cognitive enterprise, they saw it as important for 'what it can reveal about the nature of the human mind and intelligence' (p. 5) and then went on to list a whole number of contributions that SLA can make to linguistics and psychology. Ortega (2009) saw the fundamental question that SLA addresses is 'how do humans learn languages after they learn their first?' (p. 1). She recognized its interdisciplinary nature and its usefulness for addressing real-world problems such as when best to start learning a second language, overcoming negative attitudes to immigrants, and making instruction effective. In the second edition of my own survey book published in 2015, I continued to see the main value of SLA as contributing to language teaching, arguing that 'an understanding of how learners learn a second language' is 'an essential requirement for language teachers' (p. 3).

These survey books identify four main reasons for doing SLA. The first - chronologically at least is the insights it can provide about how to teach languages. The second is its contribution to social practice - for example, informing policy making about immigrant populations. Third, it can assist 
the development of its parent disciplines by serving as a testing ground for linguistic, cognitive and social theories. The fourth reason is academic curiosity. These four reasons reflect a divide between the view that SLA is a sub-branch of applied linguistics and that it is an independent discipline with ties to other academic disciplines - especially linguistics and cognitive psychology - but also separate from them. I will now address these different conceptualizations of SLA.

\section{SLA - a scientific discipline or an applied field of enquiry?}

So far I have attempted to characterize SLA in terms of the particular aspects of L2 acquisition it has addressed, the methodologies it has employed, and the reasons given for doing it. I am aware that this characterization is incomplete. For example, I have omitted to mention a number of developments the emergence of research investigating computer-assisted L2 learning and neurolinguistics SLA. I have also excluded any mention of a major strand of SLA - the role of form-focused instruction. However, I will consider this strand below as it is relevant to how I think we should view SLA.

First, though, we need to ask whether SLA is a discipline. This is not an easy question to answer. SLA has fragmented over the years, especially following the social turn, and is now heterogeneous in both its knowledge bases, its epistemologies and its methods. This is of concern to some SLA researchers. DeKeyser (2010), for example, found the bifurcation in SLA that arose with the social turn 'worrisome for those such as himself who have a vested interest in SLA' because 'if this trend continues, second language acquisition (SLA) will be absorbed completely into psycholinguistics or cognitive psychology, on the one hand, and anthropology or sociology, on the other hand' (p. 247). However, SLA it is arguably not different from such other widely recognized academic disciplines in the social sciences (e.g. psychology, sociology and education), which have elastic boundaries and multiple theories that are prone to disputation. Kuhn (1962) suggested that as a discipline matures, a paradigm emerges that sets limits on the domain of enquiry but this does not always happen and clearly not in SLA.

In a thought-provoking discussion of academic disciplines, Krishnan (2009) proposed a discipline has six defining characteristics (see the headings in the following sub-sections). I will consider each in relation to how SLA has developed and attempt to reach a conclusion as to whether SLA constitutes a scientific discipline or an applied field of enquiry.

\section{The object of enquiry in SLA is L2 acquisition}

This first characteristic is that any discipline must have a definite object of enquiry. In the case of SLA, the object of enquiry would seem to be self-evident: L2 acquisition. Looking through the historical phases, this is very clearly the case up to the social turn. At this point, however, the object of enquiry shifted to include the social uses of an L2 and the factors that influence these. At this point 'learning' took a back seat. Norton's (2000) seminal work on social identity, for example, talks only of 'learning opportunities' and assumes that where there is opportunity, learning would happen but without demonstrating that it did. To show that language learning has taken place it is necessary to show that there is some change in how the L2 is used and minimally this involves comparing samples of learnerlanguage at two different times (Ellis, 2010). Investigating learning-as-participation - as in research informed by Lave and Wenger's (1991) Community of Practice Theory - is a worthy object of enquiry but as Sfard (1998) pointed out, investigating 'participation' by itself is not enough; it is also necessary to investigate 'acquisition'.

Thus, if SLA is to constitute a coherent body of knowledge the focus must be clearly on how people LEARN an L2, not just on how they USE it in social settings. One way of ensuring a focus on learning is to delimit the scope of SLA by acknowledging cognitive psychology as the 'institutional choice' for SLA and the psycholinguistic processes of acquisition as the primary object of inquiry. This is what Long and Doughty (2003) propose. They argue that taking 'external behaviour ... not mental states as the 
proper domain of enquiry' leads to fragmentation - an 'abyss' (p. 866), where SLA is a no longer a viable discipline.

To my mind, this position is too extreme. Not all socially oriented L2 researchers limit themselves to investigating L2 use. There are examples of postmodern studies that make the link between 'participation' and 'acquisition'. Markee (2008), for example, employed a learning-tracking methodology to investigate how learning takes place over time. This involves identifying when a specific linguistic object occurs in the interactions involving the same learner, using the techniques of conversational analysis to describe what happens, and thereby plotting the changes that occur in these objects over time. Sociocultural theory also has a clear focus on language learning and, like cognitive-interactionist theories, provides a theoretical basis for linking external behaviour to internal representation. However, sociocultural SLA differs from cognitive-interactionist theories in seeing development occurring initially wITHIN interaction - that is, it claims that learning is initially a social phenomenon. Subsequently, as other regulation gives way to self-regulation, internalization occurs. While it is true that some sociocultural researchers focus only on the social uses of an L2, others aim to show that learning takes place and make use of the same kind of experimental designs as cognitively oriented researchers. ${ }^{4}$

\section{Specialist knowledge}

As my brief history of SLA shows, SLA, like any discipline, manifests shifting and expanding knowledge formations. SLA has always been ready to draw on specialist knowledge from other disciplines L1 acquisition, cognitive psychology, sociology, anthropology, education - readily borrowing constructs from them. The claim that there is a body of knowledge unique to SLA, then, relies less on the originality of the constructs themselves, than on how borrowed constructs are adapted and incorporated into SLA. A good, current example is Complex Dynamic Systems Theory. This draws on Chaos Theory taken from physics but has re-modelled the theory to take account of established characteristics of learner-language (e.g. variability and emergent properties).

The published surveys of SLA are a testimony to the richness of the specialized knowledge that has accumulated over the years. There is now a set of observations about the nature of L2 learning (e.g. a good deal of L2 acquisition happens incidentally; learners' output follows predictable paths; there are limits on the effects of instruction on learning ${ }^{5}$ ) that is widely accepted by SLA researchers and serves as the knowledge base for the field.

\section{Theories that effectively organize the knowledge base of SLA}

A mature discipline should be able to point to a theory that provides a full and convincing explanation of the object of enquiry. In this respect, SLA falls short. There is no shortage of theories but there is no widely accepted theory that provides a unifying account of L2 acquisition. The general picture is of a plethora of theories that address specific aspects of L2 learning. Some of these are 'strong' theories that have a tribal following. Processability Theory (Pienemann, 1998), for example, offers an explanation for acquisition sequences; the Interaction Hypothesis (Long, 1996) offers an account of how interaction triggers the mental processes involved in acquisition; usage-based theories (e.g. N. Ellis, 2015) provide a convincing account of how development arises from input/interaction. However, even these strong theories are subject to criticism - not all researchers agree there are universal acquisition sequences, and sociocultural theory offers a very different account of the role of interaction in learning to that of Long.

The existence of multiple theories is not necessarily a problem. In his historical perspective on academic disciplines, Krishnan (2009) distinguished the formation stage of a discipline, where leaders in the field define what the new discipline is about and provide a clear agenda for research, from a later stage where researchers consolidate the field and the discipline takes on coherence and orthodoxy. He argues that in the early, formative stage, multiple perspectives are both inevitable and desirable but that eventually the discipline needs a stable identity to survive. The question arises, then, what stage has SLA reached? I would argue that it is still in the formative period - 50 years is not long in the history 
of a discipline - and that we should be tolerant of diversity while setting guidelines (such as those proposed by Jordan, 2003) for evaluating theories.

Other researchers, such as DeKeyser (2010), are fearful that SLA is disintegrating and are keen to move SLA into its mature stage by culling theories and striving for a unified approach. There are recent signs of this happening in Complex Dynamic Systems Theory. However, as I have already indicated, I have my doubts about this theory, not least because it offers no predictions about L2 acquisition and resists generalization. If SLA is a 'pure' discipline, not claiming to be of value to society, a theory that eschews generalization may have a place, but if SLA is an applied discipline, then surely there is a need for generalizations that can inform applications. What does Complex Dynamic Systems Theory have to say to teachers, for example? Telling teachers that language learning is complex, idiosyncratic and unpredictable might be helpful in developing their awareness of the nature of L2 learning but it does not offer any practical suggestions about how to the design and implement language instruction. That requires a theory - or a number of theories - that makes specific generalizations about what and how to teach. There are other theories (e.g. Processing Theory (VanPatten, 1996)) that are less comprehensive but offer helpful predictions about L2 learning and are better suited to application.

I do not think that SLA has reached the mature stage in the development of a discipline but, like Hulstijn (2013), I do not see the plethora of theories as problematic and I am not concerned about the lack of a single, unifying perspective. SLA is a new discipline, parasitic on other disciplines, so multiple theories are inevitable. I do not know when or if SLA will mature into a stage where it provides the coherent body of knowledge of an established discipline and I wonder, in fact, whether this actually happens even in well-established disciplines in the social sciences. I think it very possible that the process of fragmentation will continue and distinct sub-areas - e.g. cognitive SLA, linguistic SLA, sociocultural SLA, instructed SLA - will consolidate. The appearance of journals devoted to each of these areas is evidence that consolidation is already happening. If SLA is an applied rather than a pure discipline, diversity is no bad thing.

\section{Specific terminologies referring to the research object}

In this respect, at least, SLA has a strong claim to be a discipline. In writing my own survey books, I became very aware of the ever-growing number of technical terms and the problem this creates for newcomers to SLA. This is why I included glossaries in my books. However, just as there is no single disciplinary perspective in SLA so there is no clear agreement about a set of core terms. Loewen and Reinders' (2011) Key concepts of language acquisition is the most comprehensive record of SLA terms to date but these authors also acknowledge that they may have omitted some terms that other researchers would see as central and included some that others see as peripheral.

\section{Specific research methods}

I have already taken note of the developments in the research methods employed by SLA. Just as SLA researchers have derived its specialist knowledge from external sources, so too they have borrowed research methods and then shaped them to suit their own needs. SLA, then, has not so much developed its own research methods as utilized and adapted existing tools. Sometimes, however, the level of adaptation is so great as to warrant the claim that the methods are novel. Good examples are taxonomies of strategies used in the negotiation of meaning (Long, 1983; Varonis \& Gass, 1985), measures of complexity, accuracy and fluency used to investigate L2 production, (Housen, Kuiken, \& Vedder, 2012), and tests of implicit and explicit L2 knowledge (Ellis, 2005).

\section{Institutional manifestation}

If institutional manifestation is a key characteristic of a discipline, then clearly SLA has a way to go. While it is true that there are now specialist SLA journals (e.g. Studies in Second Language Acquisition) and 
Table 6. Characteristics of an academic discipline (based on Krishnan, 2009)

\begin{tabular}{|c|c|}
\hline Characteristic & Applied to SLA \\
\hline 1. There is a particular object of research. & $\begin{array}{l}\text { The object of enquiry in SLA is the acquisition of a } \\
\text { second language. }\end{array}$ \\
\hline $\begin{array}{l}\text { 2. There is an accumulated specialist knowledge } \\
\text { referring to the object of research not generally } \\
\text { shared with another discipline. }\end{array}$ & $\begin{array}{l}\text { Since its inception in the } 1960 \text { s, SLA has drawn on } \\
\text { knowledge from different established disciplines and } \\
\text { adapted this as a specialized knowledge about L2 } \\
\text { acquisition. }\end{array}$ \\
\hline $\begin{array}{l}\text { 3. There are theories and concepts that can organize } \\
\text { the accumulated knowledge effectively. }\end{array}$ & $\begin{array}{l}\text { There are multiple theories and numerous concepts } \\
\text { used to organize and explain the accumulated } \\
\text { knowledge but there is little sign of the emergence of } \\
\text { a unifying theory or of agreement about the } \\
\text { boundaries of the field. }\end{array}$ \\
\hline $\begin{array}{l}\text { 4. There are specific terminologies referring to the } \\
\text { research object. }\end{array}$ & $\begin{array}{l}\text { There is a wealth of specialist terminologies but no } \\
\text { agreed set of common core terms. }\end{array}$ \\
\hline 5. Specific research methods have been developed. & $\begin{array}{l}\text { SLA has largely borrowed its research methodologies } \\
\text { from other disciplines but has applied them in } \\
\text { creative ways. }\end{array}$ \\
\hline $\begin{array}{l}\text { 6. There is some institutional manifestation in the form } \\
\text { of subjects taught at universities in academic } \\
\text { departments practising the discipline. }\end{array}$ & $\begin{array}{l}\text { There are few SLA departments in universities. SLA } \\
\text { researchers locate in different departments } \\
\text { depending on their area of expertise. }\end{array}$ \\
\hline
\end{tabular}

specialist SLA conferences (e.g. Second Language Research Forum) that thrive, it is also true that there are few departments of SLA in universities. We can find SLA researchers in departments of linguistics, psychology, sociology, foreign languages, education and even English. These researchers are just as likely to attend conferences in these disciplines or general conferences in applied linguistics such as the Applied Linguistics Association of Linguistics/Applied Linguistics Association of New Zealand (ALAA/ALANZ) conference as specialist SLA conferences. SLA researchers are often very isolated and unable to form a community of practice in their work place as they are likely to be dispersed in different academic departments - Education, English, Foreign Languages, Psychology, Sociology, Anthropology. University managers generally do not perceive SLA as of sufficient social or economic relevance or of sufficient marketability to justify the expense of setting up a new department. However, they recognize its interdisciplinary value in contributing to teaching and research in more established disciplines. If SLA is a discipline, its institutional manifestation points to it being an applied rather than a pure one.

\section{Conclusion}

The history of SLA is not a long one but it has clearly come a long way, continually expanding its boundaries, leading to questioning as to whether it can claim to be a discipline, which arguably has been the goal of some researchers. Table 6 lists Krishnan's six characteristics of a discipline along with my summative comments about how they apply to SLA. Krishnan (2009) acknowledged that not all disciplines manifest all six characteristics but that the more boxes a discipline ticks 'the more likely it becomes that a certain field of academic enquiry is recognised as a discipline capable of reproducing itself and building upon a growing body of scholarship' (p. 10). Overall, SLA does not convincingly tick any of the boxes. Disagreement exists about the object of enquiry and about the boundaries of SLA. Its specialist knowledge, specialist terminologies and methods largely derive from other disciplines although they are used creatively. There is no unifying theory or even agreement about the boundaries of SLA. Tellingly, there is only limited evidence of any institutional manifestation of SLA. We might conclude that SLA is still at the early stage of becoming a discipline and, in support of this, point to some degree of autonomy it has achieved. 
However, a more convincing conclusion is that the relevance of SLA lies in the contribution it can make to well-established disciplines and to addressing practical problems. In this respect, it is not an autonomous discipline but a sub-field of applied linguistics. If we take this perspective, we do not need to worry about fragmentation and the lack of a general, unifying theory. This is the position that Hulstijn (2013) takes. He distinguished two types of disciplines, each drawing on different kinds of theories. On the one hand there are those disciplines that address 'fundamental issues' such as the existence of linguistic universals or how language has evolved in the human species and on the other there are disciplines that address issues of 'an applied mainly educational nature' (p. 515). The former require theories where ideas are testable in ways that allow for replication (i.e. they can serve as a basis for scientific enquiry). Long's Interaction Hypothesis is a good example. The latter, however, can justifiably draw on pre-scientific theories (i.e. theories that incorporate ideas that are not testable) as long as these ideas are of practical value. Krashen's Monitor Model is a good example. If we accept that SLA is not a discipline but rather is parasitic on and contributory to other disciplines in different ways, then, we do not need to cull useful theories simply on the grounds they are not scientific. $^{6}$ SLA will inevitably be theoretically multifarious.

SLA was an applied field of study from the beginning and I think that fundamentally it still is although sadly applications seem to have become less prevalent in the drive to establish SLA as an autonomous, scientific discipline. SLA researchers, for example, are less ready to apply the findings of their research to language teaching - the most obvious area of application. I undertook an analysis of the articles published in Studies in Second Language Acquisition ${ }^{7}$ in 2018 to see whether they included any pedagogical applications and implications. Out of 35 research articles, only five did so and two of these only briefly. This is a long cry from the contents of early issues of this journal, which, before Cambridge University Press took it over, was published under the sponsorship of the Center for English Language Training (CELT) and the Committee for Research and Development in Language Instruction (CREDLI), with a clear emphasis on publishing pedagogically focused articles (Valdman, 1999). Language pedagogy is, of course, not the only target of possible applications - others are linguistics, psychology, sociology and anthropology - but it is arguably the main one. Each area of application will draw on a different strand of SLA and strands relevant to all of these disciplines exist in SLA today. If we accept that SLA is fundamentally an applied area of enquiry, diversity is no longer a problem and there will be no need for turf battles over boundaries of SLA. I would add, though, we do need to agree that the object of enquiry is L2 learning, not just L2 use, which is the business of sociology and anthropology.

As an interdisciplinary field of enquiry, SLA will continue to accumulate a diverse body of knowledge attuned to the particular applications it seeks to make. Let us hope that SLA researchers do not feel obliged to demonstrate their credentials as members of an autonomous SLA discipline by omitting to make applications.

\footnotetext{
Notes

1 Like Ortega (2009), I use 'SLA' to refer to field of enquiry and 'L2 acquisition' to refer to the object of investigation. This distinction is not common, however. Often 'SLA' is used to refer to both the field and object of enquiry.

${ }^{2}$ It is widely accepted that the starting point of SLA was the 1960s. Corder published his seminal article 'The significance of learner errors' in 1967. Nemser published his 'Approximate systems of foreign language learners' in 1971. Selinker published 'Interlanguage' in 1972. These three articles presented the case for viewing L2 acquisition as a transitional process where learners tested hypotheses in much the same way as in L1 acquisition. These articles motivated what had been previously lacking - the empirical study of learner language.

${ }^{3}$ Larsen-Freeman and Cameron (2008) argue that Complexity Theory is 'more than a metaphor if it takes us to a new way of thinking or theoretical framework, that is then rigorously developed in the field' (p. 15). However, they do not address the fundamental requirement of any theory; namely is it testable.

${ }^{4}$ Sociocultural SLA does differ from cognitive SLA in one of the ways in which it conceptualizes learning. For Lantolf, learning is evident when a learner has achieved self-regulation and thus can independently produce a target language form that he/ she could not produce earlier but it is also evident if there is a reduction from one time to another in the level of otherregulation needed for the learner to produce the target form.
} 
5 These observations about L1 acquisition come from VanPatten and Williams (2007). They listed ten observations that they suggested provide a basis for evaluating different SLA theories. It is noticeable that all the observations derive from a cognitive model of L2 acquisition.

${ }^{6}$ However, as Hulstijn pointed out, it would be helpful if scholars were more transparent in identifying ideas not yet ready for empirical testing.

${ }^{7}$ I chose Studies in Second language Acquisition, as SLA researchers view this as the primary journal in SLA. I acknowledge, however, that other journals (e.g. Language Teaching Research) draw on SLA.

\section{References}

Anderson, J. (1980). Cognitive psychology and its implications. San Francisco, NC: Freeman.

Atkinson, D. (2014). Language learning in mindbodyworld: A sociocognitive approach to second language acquisition. Language Teaching, 47(4), 467-483.

Barkhuizen, G. (2014). Narrative research in language teaching and learning. Language Teaching, 47(4), 450-466.

Block, D. (2003). The social turn in second language acquisition. Edinburgh, UK: Edinburgh University Press.

Blum-Kulka, S., House, J., \& Kasper, G. (1989). Cross-cultural pragmatics: Requests and apologies. Norwood, NJ: Ablex.

Bourdieu, P. (1986). The forms of capital. In J. F. Richardson (Ed.), Handbook of theory and research for the sociology of education (pp. 241-258). New York, NY: Greenwood Press.

Brown, P., \& Levinson, S. (1987). Politeness: Some universals in language usage. Cambridge, UK: Cambridge University Press.

Brown, R. (1973). A first language: The early stages. Cambridge, MA: Harvard University Press.

Cancino, H., Rosansky, E., \& Schumann, J. (1978). The acquisition of English negatives and interrogatives by native Spanish speakers. In E. Hatch (Ed.), Second language acquisition (pp. 207-230). Rowley, MA: Newbury House.

Chomsky, N. (1965). Aspects of the theory of syntax. Cambridge, MA: MIT Press.

Comrie, B. (1984). Language universals and linguistic typology. Oxford, UK: Basil Blackwell.

Cook, V. J. (1992). Evidence for multicompetence. Language Learning, 42(4), 557-591.

Corder, S. P. (1967). The significance of learners' errors. International Review of Applied Linguistics, 5, 161-169.

Coulthard, M. (1977). An introduction to discourse analysis. Harlow, UK: Longman.

Davis, K. (2012). Ethnographic approaches to second language acquisition research. The Encyclopaedia of Applied Linguistics. doi:10.1002/9781405198431.wbeal0399

de Bot, K., Lowie, W., \& Verspoor, M. (2007). A dynamic systems theory approach to second language acquisition. Bilingualism: Language and Cognition, 10(1), 7-21.

DeKeyser, R. (1998). Beyond focus on form: cognitive perspectives on learning and practicing second language grammar. In C. Doughty, \& J. Williams (Eds.), Focus on form in classroom second language acquisition (pp. 42-63). Cambridge, UK: Cambridge University Press.

DeKeyser, R. (2010). Where is our field going? Comments from the outgoing editor of Language Leaning. Modern Language Journal, 944(4), 646-647.

Doughty, C., \& Long, M. (2003). The scope of inquiry and goals of SLA. In C. Doughty, \& M. Long (Eds.), The handbook of second language acquisition (pp. 3-16). Malden, MA: Blackwell.

Dulay, H., \& Burt, M. (1973). Should we teach children syntax? Language Learning, 23(2), 245-258.

Dulay, H., \& Burt, M. (1975). Creative construction in second language learning and teaching. In M. Burt, \& H. Dulay (Eds.), On TESOL '75: New directions in second language learning, teaching and bilingual education (pp. 21-32). Washington, DC: TESOL.

Eckman, F., Bell, L., \& Nelson, D. (1988). On the generalization of relative clause instruction in the acquisition of English as a second language. Applied Linguistics, 9(1), 1-20.

Ellis, N. (1994). Implicit and explicit learning of languages. San Diego: Academic Press.

Ellis, N. (2015). Usage-based approaches in second language acquisition. In B. VanPatten, \& J. Williams (Eds.), Theories in second language acquisition (pp. 75-93). Mahwah, NJ: Lawrence Erlbaum.

Ellis, R. (1985). Understanding second language acquisition. Oxford, UK: Oxford University Press.

Ellis, R. (1994). A theory of instructed second language acquisition. In N. Ellis (Ed.), Implicit and explicit learning of languages (pp. 79-114). San Diego, CA: Academic Press.

Ellis, R. (2005). Measuring implicit and explicit knowledge of a second language: A psychometric study. Studies in Second Language Acquisition, 27(2), 141-172.

Ellis, R. (2010). Theoretical pluralism in SLA: Is there a way forward? In P. Seedhouse, S. Walsh, \& C. Jenks (Eds.), Conceptualising 'learning' in applied linguistics (pp. 23-51). Basingstoke, UK: Palgrave Macmillan.

Ellis, R. (2015). Understanding second language acquisition (2nd ed.). Oxford, UK: Oxford University Press.

Ellis, R., \& Barkhuizen, G. (2005). Analyzing learner language. Oxford, UK: Oxford University Press.

Ferguson, C. (1975). Towards a characterization of English foreigner talk. Anthropological Linguistics, 17(1), 1-14.

Firth, A., \& Wagner, J. (1997). On discourse, communication, and (some) fundamental concepts in SLA. Modern Language Journal, 81(3), 285-300. 
Firth, A., \& Wagner, J. (2007). Second/foreign language learning as a social accomplishment: Elaborations on a reconceptualized SLA. Modern Language Journal, 91(S1), 800-819.

Gass, S. (1984). A review of interlanguage syntax: Language transfer and language universals. Language Learning, 34(2), 115-132.

Hatch, E. (1978a). Second language acquisition. Rowley, MA: Newbury House.

Hatch, E. (1978b). Apply with caution. Studies in Second Language Acquisition, 2(1), 123-143.

Housen, A., Kuiken, F., \& Vedder, I. (2012). Complexity, accuracy and fluency: Definitions, measurement and research. In A. Housen, F. Kuiken, \& I. Vedder (Eds.), Dimensions of L2 performance and proficiency: Investigating complexity, accuracy and fluency in SLA (pp. 1-20). Amsterdam, Netherlands: John Benjamins.

Hulstijn, J. (2013). Is the second language acquisition discipline disintegrating? Language Teaching, 46(4), 511-517.

Jordan, G. (2003). Theory construction in second language acquisition. Amsterdam, Netherlands: John Benjamins.

Kellerman, E. (1983). Now you see it, now you don't. In S. Gass, \& L. Selinker (Eds.), Language transfer in language learning (pp. 112-134). Rowley, MA: Newbury House.

Klima, E., \& Bellugi, V. (1966). Syntactic regularities in the speech of children. In J. Lyons, \& R. Wales (Eds.), Psycholinguistic papers (pp. 183-208). Edinburgh, UK: Edinburgh University Press.

Krashen, S. (1977). Some issues relating to the Monitor Model. In H. Brown, C. Yorio, \& R. Crymes (Eds.), On TESOL '77 (pp. 152-161). Washington, DC: TESOL.

Krashen, S. (1981). Second language acquisition and second language learning. Oxford, UK: Pergamon.

Krashen, S. (1983). Newmark's ignorance hypothesis and current second language acquisition theory. In S. Gass, \& L. Selinker (Eds.), Language transfer in language learning (pp. 135-153). Rowley, MA: Newbury House.

Krashen, S. (1985). The Input Hypothesis: Issues and implications. London, UK: Longman.

Krishnan, A. (2009). What are academic disciplines? Some observations on the disciplinarity versus interdisciplinarity. NCRM Working Paper Series: ESRC National Centre for Research Methods.

Kuhn, T. (1962). The structure of scientific revolutions. Chicago, IL: University of Chicago Press.

Lado, R. (1957). Linguistics across cultures: Applied linguistics for language teachers. Ann Arbor, MI: University of Michigan. Lantolf, J. (1996). Second language theory building: letting all the flowers bloom! Language Learning, 46(4), 713-749.

Lantolf, J. (2000). Sociocultural theory and second language learning. Oxford, UK: Oxford University Press.

Larsen-Freeman, D. (1997). Chaos/complexity science and second language acquisition. Applied Linguistics, 18(2), $141-165$.

Larsen-Freeman, D. (2018). Looking ahead: Future directions in, and future research into, second language development. Foreign Language Annals, 51(1), 55-72.

Larsen-Freeman, D., \& Cameron, L. (2008). Complex systems and applied linguistics. Oxford, UK: Oxford University Press. Larsen-Freeman, D., \& Long, M. H. (1991). An introduction to second language acquisition research. London, UK: Longman.

Lave, J., \& Wenger, E. (1991). Situated learning: Legitimate peripheral participation. Cambridge, UK: Cambridge University Press.

Loewen, S., \& Gass, S. (2009). The use of statistics in L2 acquisition research. Language Teaching, 42(2), $181-196$.

Loewen, S., \& Reinders, S. (2011). Key concepts in second language acquisition. Basingstoke, UK: Palgrave MacMillan.

Long, M. (1983). Native speaker/non-native speaker conversation and the negotiation of comprehensible input. Applied Linguistics, 4(2), 126-141.

Long, M. (1985). A role for instruction in second language acquisition: Task-based language teaching. In K. Hyltenstam, \& M. Pienemann (Eds.), Modelling and assessing second language acquisition (pp. 77-99). Bristol, UK: Multilingual Matters.

Long, M. (1993). Assessment strategies for SLA theories. Applied Linguistics, 14, 225-249.

Long, M. (1996). The role of the linguistic environment in second language acquisition. In W. Ritchie, \& T. Bhatia (Eds.), Handbook of second language acquisition (pp. 413-468). San Diego, CA: Academic Press.

Long, M. (1998). SLA breaking the siege. University of Hawai'i Working Papers in ESL, 17(1), 79-129.

Long, M., \& Doughty, C. (2003). SLA and cognitive science. In C. Doughty, \& M. Long (Eds.), The handbook of second language acquisition (pp. 866-870). Malden, MA: Blackwell.

Mackey, A., \& Gass, S. (Eds.) (2016). Second language research: Methodology and design (2nd ed.). New York, NY: Routledge. Markee, N. (2008). Toward a learning behavior tracking methodology for CA-for-SLA. Applied Linguistics, $29(3), 404-427$. May, S. (2013). The multilingual turn: Implications for SLA, TESOL and bilingualism. New York, NY: Routledge.

Mitchell, R., \& Myles, F. (1998). Second language learning theories. London, UK: Hodder Arnold.

Nemser, W. (1971). Approximative systems of foreign language learners. International Review of Applied Linguistics, 9(2), 115-123.

Newmark, L. (1966). How not to interfere in language learning. International Journal of American Linguistics, 32(1), $77-87$. Norris, J., \& Ortega, L. (2000). Effectiveness of L2 instruction: A research synthesis and quantitative meta-analysis. Language Learning, 50(3), 417-528.

Norton, B. (2000). Identity and language learning: Gender, ethnicity and educational change. Harlow, UK: Longman.

Norton Peirce, B. (1995). Social identity, investment, and language learning. TESOL Quarterly, 29(1), 9-31.

Ortega, L. (2009). Understanding Second Language Acquisition. London, UK: Hodder Education.

Ortega, L. (2019). SLA and the study of equitable multilingualism. Modern Language Journal, 103, Supplement, 23-38. 
Ortega, L., \& Byrnes, H. (2008). The longitudinal study of advanced L2 capacities. New York, NY: Routledge.

Pienemann, M. (1998). Language processing and second language development: Processability Theory. Amsterdam, Netherlands: John Benjamins.

Plonsky, L. (2015). Advancing quantitative methods in second language research. New York, NY: Routledge.

Reber, A. (1976). Implicit learning of synthetic learners: The role of instructional set. Journal of Experimental Psychology, Human Learning and Memory, 2, 88-94.

Reber, A. (1993). Implicit learning and tacit knowledge: An essay on the cognitive unconscious. Oxford, UK: Oxford University Press.

Révész, A., Michel, M., \& Gilabert, R. (2016). Measuring cognitive task demands using dual task methodology, subjective self-ratings, and expert judgments: A validation study. Studies in Second Language Acquisition, 38(4), $703-737$.

Ringbom, H. (1987). The role of the first language in foreign language learning. Bristol, UK: Multilingual Matters.

Schmidt, R. (1990). The role of consciousness in second language learning. Applied Linguistics, 11(2), 129-158.

Schmidt, R., \& Frota, S. (1986). Developing basic conversational ability in a second language: A case study of an adult learner. In R. Day (Ed.). Talking to learn: Conversation in second language acquisition (pp. 237-326). Rowley, MA: Newbury House.

Schumann, F., \& Schumann, J. (1977). Diary of a language learner: An introspective study of second language learning. In H. Brown, C. Yorio, \& R. Crymes (Eds.), On TESOL '77 (pp. 241-249). Washington, DC: TESOL.

Schumann, J. (1978). The acculturation model for second language acquisition. In R. Gingras (Ed.), Second language acquisition and foreign language teaching (pp. 27-50). Arlington, VA: Center for Applied Linguistics.

Searle, J. (1969). Speech acts. Cambridge, UK: Cambridge University Press.

Selinker, L. (1972). Interlanguage. International Review of Applied Linguistics, 10(3), 209-231.

Sfard, A. (1998). On two metaphors for learning and the dangers of choosing just one. Educational Researchers, 27(2), 4-13.

Sharwood-Smith, M. (1994). Second language learning: Theoretical foundations. London, UK: Longman.

Swain, M. (1985). Communicative competence: Some roles of comprehensible input and comprehensible output in its development. In S. Gass, \& C. Madden (Eds.), Input in second language acquisition (pp. 235-253). Rowley, MA: Newbury House.

Swain, M. (2006). Languaging, agency and collaboration in advanced second language learning. In H. Byrnes (Ed.), Advanced language learning: The contributions of Halliday and Vygotsky (pp. 95-108). London, UK: Continuum.

Thomas, J. (1983). Cross-cultural pragmatic failure. Applied Linguistics, 4(2), 91-112.

Tomlin, R., \& Villa, V. (1994). Attention in cognitive science and second language acquisition. Studies in Second Language Acquisition, 16, 183-203.

Valdman, A. (1999). A note from the editor: 20th anniversary of SSLA. Studies in Second Language Acquisition, 20(4), 463-470.

VanPatten, B. (1996). Input processing and grammar instruction in second language acquisition. Norwood, NJ: Ablex.

VanPatten, B., \& Williams, J. (2007). Introduction. In B. VanPatten, \& J. Williams (Eds.), Theories in second language acquisition (pp. 1-16). Mahwah, NJ: Lawrence Erlbaum.

Varonis, E., \& Gass, S. (1985). Non-native/non-native conversations: A model for negotiation of meaning. Applied Linguistics, 6(1), 71-90.

Vygotsky, L. (1978). Mind in society. Cambridge, MA: MIT Press.

Vygotsky, L. (1986). Thought and language (Newly revised and edited by A. Kozulin). Cambridge, MA: MIT Press.

Wells, G. (1985). Language development in the pre-school years. Cambridge, UK: Cambridge University Press.

White, L. (1989). Universal grammar and second language acquisition. Amsterdam, Netherlands: John Benjamins.

Wode, H. (1976). Developmental sequences in naturalistic L2 acquisition. Working Papers on Bilingualism, 1(1), 1-13.

Rod Ellis is currently a Research Professor in the School of Education, Curtin University in Perth, Australia. He is also a professor at Anaheim University, a visiting professor at Shanghai International Studies University, an Emeritus Professor of the University of Auckland, and a fellow of the Royal Society of New Zealand. His published work includes articles and books on SLA, language teaching, and teacher education. His latest books are Becoming and being an applied linguist (John Benjamins, 2016) and Reflections on task-based language teaching (Multilingual Matters, 2018). He has held university positions in six different countries and has conducted numerous consultancies and seminars throughout the world. His current interests are task-based language teaching and the assessment of L2 learners' pragmatic knowledge.

Cite this article: Ellis, R. (2021). A short history of SLA: Where have we come from and where are we going? Language Teaching, 54(2), 190-205. https://doi.org/10.1017/S0261444820000038 